\title{
Climate change in winter sport destinations - transdisciplinary research for implementing sustainable tourism
}

U. Pröbstl ${ }^{1}$, A. Prutsch ${ }^{1}$, H. Formayer ${ }^{1}$, M. Landauer ${ }^{1}$, K. Grabler ${ }^{2}$, A. Kulnig ${ }^{2}$, M. Jesch ${ }^{2}$, E. Dallhammer ${ }^{3}$ \& C. Krajasits ${ }^{3}$

${ }^{1}$ BOKU - University of Natural Resources and Applied Life Sciences,

Vienna, Austria

${ }^{2}$ Manova NetBusiness Solutions GmbH, Vienna, Austria

${ }^{3}$ ÖIR - Austrian Institute for Spatial Planning, Vienna, Austria

\begin{abstract}
Climate change and its possible consequences for winter vacation destinations constitutes a new and complex challenge to tourism research. The actual effects of climate change, as well as its perception and presentation by the media, by politics and society at large all influence entrepreneurial decisions and the future development of a region. In order to research the future of a winter sport resort community, a transdisciplinary research framework was developed for the destination of Schladming in Austria. We evaluated the effects of climate change by investigating spatial differences on a local scale and adapting the large scaled climate change models to this local level. Then we studied the attitudes and preferences of visitors, including the possible effects of the media on public opinion. An analysis of regional economic statistics documented the strengths, weaknesses, opportunities and threats of the study area. In addition, we considered the opinions of local representatives, as well as stakeholders, interest groups and associations. These results provide background information for the first expanded implementation of the Tourism Optimization Management Model (TOMM) in Europe. In this visitor management process, local people are formulating strategic regional decisions considering climate change and other trends in tourism in order to enhance a sustainable development in their region.
\end{abstract}

Keywords: climate change, tourism, alpine area, tourism optimization management model. 


\section{Introduction}

The OECD [6], Abegg [1], Elsasser and Bürki [2] as well as Marttila et al. [5] described climate change as a severe threat to winter tourism in the European Alps. With more than 57 Million bednights in Austria alone, winter tourism is one of the most important economic sectors, especially in the inner alpine areas. In many regions winter sport tourism is even more important than summer tourism. The vulnerability of winter tourism is enhanced by its high temporal and spatial concentration. The vulnerability is exacerbated further by the fact that $70 \%$ of the accommodation capacities are located in areas below an altitude of $1.000 \mathrm{~m}$. Recent trends show that the number of winter visits is now stagnating in many regions.

The actual effects of climate change, as well as its perception and presentation by the media, by politics and society at large influence entrepreneurial decisions and the development of a region, and will continue to do so in the future. Climate change research is mostly initiated by one single discipline and therefore is limited in accommodating the complex relationships between the real effects of climate change, the presentation of these possible effects by the media, the perception and reaction of the clients and finally the decisions by the local entrepreneurs. Therefore we embarked on a transdisciplinary research project with a team of climatologists, tourism planners and market researchers, and experts in regional planning; all of them were supported by representatives of local and regional enterprises and stakeholders. To study this phenomenon we started a cooperation with the winter sport destination Schladming, which is a well known resort community in the Ennstal in Upper Styria, located between $740 \mathrm{~m}$ and $1820 \mathrm{~m}$ above sea level.

\section{Transdisciplinary research design}

A transdisciplinary research design combines several methods for creating and relating scientific knowledge and explicitly tieing the research to non-scientific experience and practice for the purpose of solving a specific problem. The problem-oriented research approach is designed to identify social and/or environmental problems, to limit their escalation, and to design sustainable solutions. The core idea is that researchers, practitioners and stakeholders must cooperate in order to address the complex challenges of society (Thomson-Klein et al. [10]). The planning process starts with a cooperative dissection of the problem so that the various disciplines can then undertake their work, but with the ultimate goal of later integration of the respective disciplinary results. The entire research process is designed to ensure the links between the single working tasks and the overall research problem. This cooparative approach is illustrated in Figure 1. A transdisciplinary style of research can only arise if the participating experts and partners interact in an open discussion and dialogue, accepting each perspective as of equal importance and relating the different 


\section{Transdisciplinary approach}

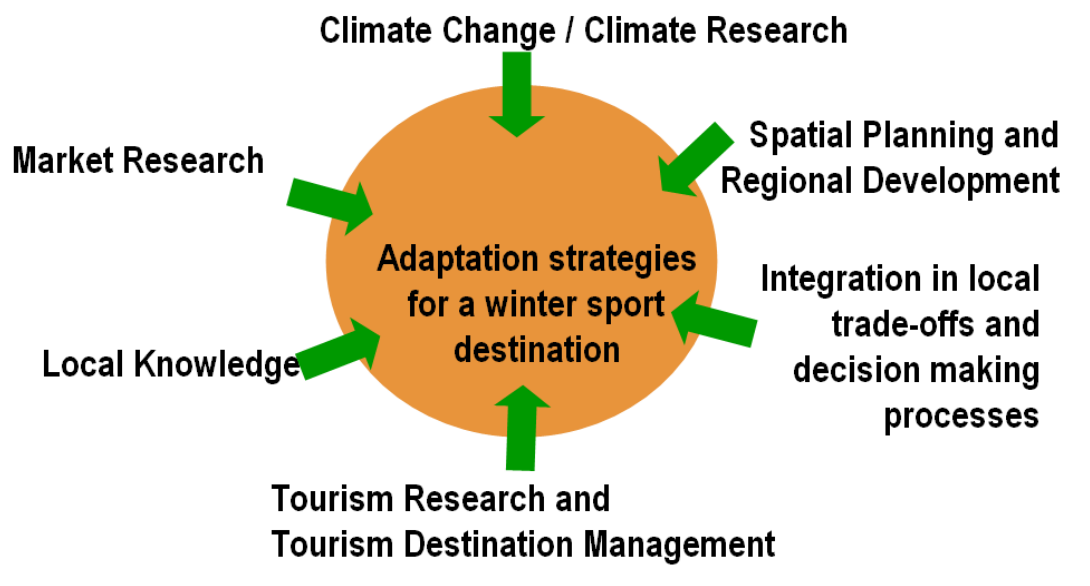

Figure 1: Complex applied problems such as the adaptation of tourism destinations to climate change require a transdisciplinary approach supported by different disciplines, methods and background.

perspectives to each other. Therefore, in this summary paper we will present the results of the respective disciplines as well as their contribution to the research process in a whole.

\section{Results}

\subsection{Climate research - findings and contributions}

The initial challenge for this research team was to adapt and downscale the climate scenarios from the European to the local level. The basis for the development of local scenarios was the global atmosphere-ocean-circulationmodel ECHAM5/MPI-OM (Roeckner [8]) and the REMO-UBA scenario A1B. Local data on snow cover had been collected by the cable car company and the official meteorological measurements on temperature, precipitation and snow cover from 1961 to 2002 were also available. The changes observed over that time period were used to calibrate the weather generator LARS-WG (Long Aston Research Station Weather Generator, see Semenov and Barrow [9]). The first analysis showed that the effects of climate change are already evident (see fig. 2). These first results also aroused public interest and enhanced the cooperative process in the destination. The results were also discussed between the research partners. For tourists, the main concern is not the natural snow cover, but the 'usable snow cover' (natural snow together with artificial snow). 
In contrast to several other studies which estimate the effects of climate change based on the natural snow cover only (see Abbegg [1], OECD [6]), we developed for Schladming a local snow model that included the conditions for snow making on an hourly basis. Against this background we were able to calculate the usable snow cover, based on both natural and artificial snow, as well as the likelihood of possible melting processes and rainfall. This information constituted an important input for the market research and the tourism management model.

Figure 2 shows that there are already significant effects due to climate change when the period 1961-1990 is compared to 1973-2002. The hours per month suitable for snow making have declined significantly for all winter months except November.

Hours per month suitable for artificial snow making (threshold - 4 degree) at Planai Mittelstation (1300 m) for the period 1961 - 1990 and $1973-2002$

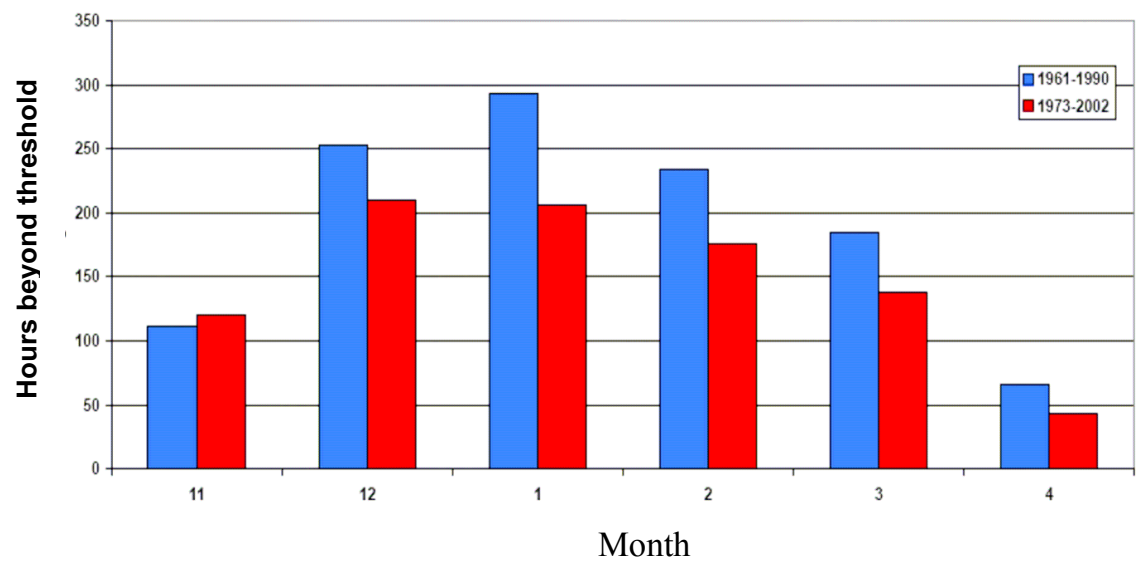

Figure 2: $\quad$ Reduced hours per month suitable for snowmaking.

Overall, it will be possible to pursue and enjoy winter sport in the area as it is undertaken today until about 2020. The existing technology for artificial snow making will be sufficient to buffer typical variations (statistically every $5^{\text {th }}$ year). Extreme weather events, during which snow making will not be possible, will occur only rarely (statistically about every $20^{\text {th }}$ year). From 2020 onwards extreme winters lacking snow, like the winter 2006/2007, will occur more frequently. Negative impacts can be reduced if the technology of snow making will be improved further and will allow snow-making at $-1{ }^{\circ} \mathrm{C}$. Finally, the models predict that after 2050 snow-making cannot ensure winter holidays any longer, as the probability of several weeks without snow will occur statistically about every $5^{\text {th }}$ year.

\subsection{Market research - findings and contributions}

Market research was used to explore the importance of snow and of the winter experience in general for tourists, how they might adjust their booking behaviour 
if confronted with less snow in the future, and finally the effect of the media in situations when resorts are lacking snow. In a primary study existing data across all of Austria (T-MONA and SAMON) were analysed. They showed that snow cover and nature experience are the most important motives for winter holidays. The results were then combined with the scenarios of the climate research model and brought back to the research team for discussion. The information also provided the background for a large online-questionnaire. In the second part a sample of 10.821 winter sport enthusiasts from Germany and Austria were recruited to the study, and 3.858 persons responded for a response rate of $35,7 \%$. These persons were contacted a second time. The questionnaire was slightly changed with additional information on climate change and its consequences on winter sport. This second phase was included to measure the possible effects by the media. Overall 2.546 respondents contributed to both phases. To simulate the real decision making process a conjoint analysis was used, where the respondents had to decide between three different winter sport destinations, which were characterised by the following attributes: altitude, amount of slopes and their degree of difficulty, snow conditions and forecast, options for technical snow, other infrastructure for recreation and different options for accommodation.

In a similar manner, a smaller sample of cross country skiers (456 respondents) was asked about their perception of and choice behaviour around climate change (Landauer and Pröbstl [4]). The attributes described structure and length of the tracks, its natural snow conditions, options for snow making and additional infrastructure. The effect of natural snow cover in the landscape was included as a picture. In the following only some selected results of both studies can presented here.

In both studies the majority (about 75\%) of winter sport enthusiasts, both cross-country and downhill skiers, answered, that the first signs of global warming can already be observed. Only about $23 \%$ of the respondents still believe it is too early to worry about it.

The stimulation with selected information showed a significant influence on the booking behaviour. There is a tendency to book late, when the snow conditions can be evaluated, to book holidays only in snow secure months and in destinations in a higher altitude. The analyses of the cross country skiers showed similar trends.

Furthermore the analyses of the down hill skiers showed a clear segmentation in four different user groups: the infrastructure oriented group, the sport oriented group, the demanding $5^{*}$-group and the price sensitive group. These user groups are characterized by a different behaviour in the case of insufficient snow conditions. For about $20 \%$ of the demanding- $5 *$-group a lack of snow for several days can be compensated by a high standard accommodation and for $35 \%$ via additional offers and services. The price sensitive segment and the infrastructure related group can be compensated up to a certain point with extremely cheap accommodation, but the majority would tend to leave. The fourth segment, the sport oriented group, would leave the ski resort first. They are not attracted by any substitute. The majority of the downhill skiers state that natural snow is 
preferred but artificial snow is also accepted. Only 5\% state that they ski on natural snow only.

Similarly, the cross country skiers tend to accept artificial skiing tracks, and are also willing to pay for them. The majority (about $53 \%$ ) would pay up to $5 €$ per day for this service (see fig.3).

These kinds of results from market research provided the background for the participatory discussion of management options with the local stakeholders during several community meetings, and also contributed to the development of new strategies.

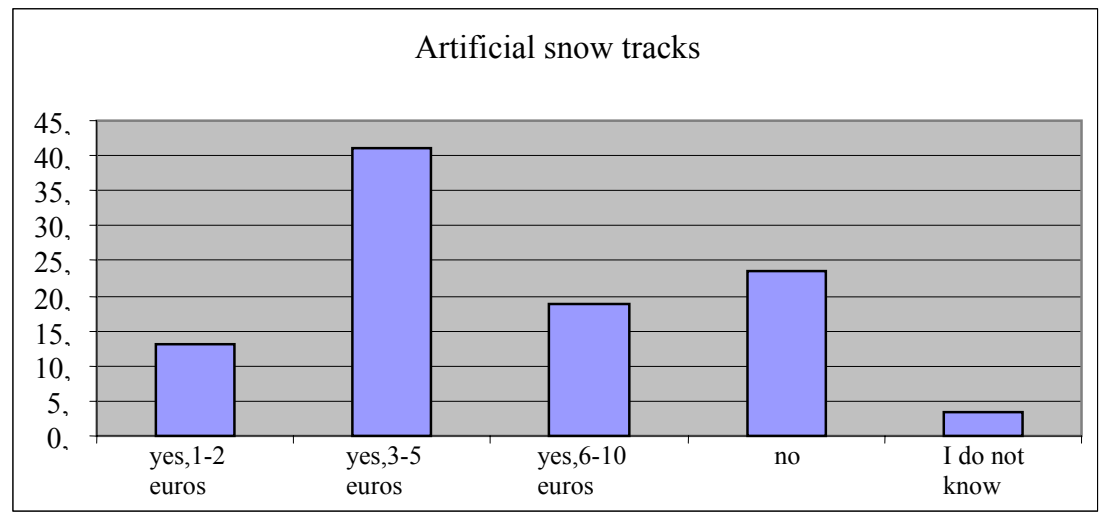

Figure 3: Opinions on willingness to pay for artificial snow tracks by crosscountry skiers.

\subsection{Spatial planning - findings and contributions}

The strategies for future development in the Schladming area must be imbedded in the regional context. This was the reason for a sound spatial and structural evaluation of the area. It turned out that in this region winter sport is about 100 years old. Since 1908 the winter sport has been increasing, but only in 1975 more bednights were recorded for the winter season compared to the summer.

Today about $70 \%$ of employment relies on the tertiary sector and about $20 \%$ thereof is based in tourism (average in Austria is 5,8\%). In 2004 and 2005 about 2 million bed nights were counted annually. A full $60 \%$ of all bed nights were booked in the winter season. These figures and a related swot analysis underline the vulnerability of the Schladming region towards the possible effects of climate change.

In interviews, the local stakeholders mentioned the effects of climate change and criticised the late booking behaviour of their guests. The regional analysis was also used to visualize the social network in that region. This study revealed that the perception of "the region" differs between actors. The challenge is that the administrative boundaries, do not coincide with the areas covered by the tourism association and the region affected by climate change. As a 
consequence, no single organization or administrative unit has a clearly defined leadership role when it comes to combating climate change. This observation is also true for other regions. In the current project, the discussion of these issues alone lead to new cooperation and suggestions for a form of new governance, once participants realized that anybody else will take leadership with regards to climate change.

\subsection{Tourism-optimization-management-model and climate change (CC-TOMM)}

The described transdisciplinary inventory and analysis provided the foundation for the ultimate goal of the project: the development of strategies focusing on the sustainable spatial development under the influence of global warming.

Several international studies show that efficient and innovative solutions emerge when the development options of a region are defined in a participatory manner between the various actors. This action space needs to be based on agreed standards, which serve as benchmarks during implementation as well as tools for communication. The TOMM (Tourism Optimization Management Model) represents a suitable framework with the explicit goal of sustainable tourism development (Hall and McArthur [3]).

TOMM was originally developed for the implementation of sustainable tourism development in an Australian destination and is globally regarded as the framework that integrates the goals and interest of the economy, science, administration and society in a comprehensive manner. The transdisciplinary character of the model meets the extensive requirements of alpine ski regions. TOMM does not define rigid limits of development, but intends to bring all process participants in a region together and to consider the facts and the desired conditions during the process of developing appropriate strategies. Workshops ensure that all interest groups continually have the opportunity to participate, which includes the insurance of an adequate balance of gender.

For the CC-TOMM in Schladming, five meta-indicators (environmental aspects, economical aspects, marketing, quality of experiences and socio-cultural aspects) described by 17 criteria were developed and tested for their relevance in the tourism, their transparency for the public, the availability of the required data, their significance towards sustainable development and their measurability over time. Furthermore the set of indicators and criteria must be sensitive to any adaptation strategy chosen by the region. In contrast to several publications in that field we made the experience that the basic structure of CC-TOMM can be developed in a cooperative manner but the set of key indicators and selected criteria must be provided by the research team. On the other hand CC-TOMM turns out to be more than simply a tool for stabilizing management and monitoring, like in its first Australian application; it is also a tool for exploring and eventually selecting different future development scenarios and for introducing them in the decision making process. It is able to motivate the public and decision makers to get involved with the challenges of global warming and to start their measures despite administrative or politically defined regions. 


\section{Summary}

This project applied TOMM for the very first time in Europe, and expanded the scope of the framework a strategic visioning tool. This strategic instrument of planning integrates local knowledge, results of climate change modelling, market research, local and regional quantitative data, and participatory regional analyses, as well as several investigations of the tourists and serves as the basis for strategic decisions in the affected area. Its major innovation is that climate research is integrated into the complex societal evaluation and regional development, and is also included in a new, participatory and action oriented management concept. At the same time, natural science research, social sciences and planning sciences are integrated in a truly transdisciplinary manner.

In our opinion the presented model of transdisciplinary research is required not only in the field of climate change, but any time when research has to deal with future uncertainties, to enhance the decision making process and to solve complex research questions by combining partners from different research fields, the local population and from the affected economic sectors. It proved to be an excellent concept to identify strategies for sustainable development in a participatory manner.

\section{References}

[1] Abbegg, B.: Klimaänderung und Tourismus: Klimafolgenforschung am Beispiel des Wintertourismus in den Schweizer Alpen. Schlussbericht NPP 31. Zusammenfassung III. Hochschulverlag AG an der ETH, Zürich, 1996.

[2] Elsasser, H. \& Bürki. Auswirkungen von Umweltänderungen auf den Tourismus - dargestellt am Beispiel der Klimaänderung im Alpenraum. In: Becker, C.; Hopfinger, H.; Steinecke, A. (eds.). Geographie der Freizeit und des Tourismus. Oldenburg Wissenschaftsverlag $\mathrm{GmbH}$ München, Deutschland.2004.

[3] Hall, M. \& McArthur S., Integrated Heritage Management: Principles and Practice. The stationery office, London, 1998.

[4] Landauer, M. \& Pröbstl, U., Skilanglauf, Klimawandel und Tourismus in Österreich, Naturschutz und Landschaftsplanung, submitted 2008.

[5] Marttila, V., Granholm, H., Laanikar, J., Yrjölä, T.; Aalto, A., Heikineheimo, P., Honkatuki, J., Järvinen, H., Liski, J., Merivirata, R., Paunio, M. : Ilmastonmuutoksen kansallinen sopeutumisstrategia. Maa- ja metsätalousministeriön (MMM) julkaisuja 1/2005. Vammalan kirjapaino. Vammala Finnland. (2005)

[6] OECD: Climate change in the European Alps: adapting winter tourism and natural hazards management. Organisation for Economic Co-operation and Development. Ed. By Shardul Agrawala. Paris. 2007.

[7] Pröbstl, U. Klimawandel: Zukunft und Herausforderung für den Tourismus, in: Ländlicher Raum, Online Zeitschrift des Bundesministeriums für Landund Forstwirtschaft, Umwelt und Wasserwirtschaft, 5/2007, 
http://www.laendlicher-raum.at/article/articleview/61179/1/10402, 2007, (accessed on 01.05.08)

[8] Roeckner, E. IPCC DDC AR4 ECHAM5/MPI-OM SRESA1B run1.CERADB “EH5_MPI_OM_SRESA1B_1, Link: http//cera-www.dkrz.de/WDCC /ui/Compact.jsp?acronym=EH5_MPI_OMSRESA1B_1, accessed 15.3 . 2005

[9] Semenov, M. \& Barrow. E., Use of a stochastic weather generator in the development of climate change scenarios. Climate change, 35, 397414.1997

[10] Thomson-Klein, J., Grossenbacher-Mansuy, W.; Häberli, R.; Bill, A.; Scholz, R.W.; Welti, M. (Eds.), Transdisciplinarity: Joint Problem Solving among Science, Technology, and Society. An Effective Way for Managing Complexity. Birkhäuser Verlag, 2000. 